\title{
'Intended' and 'unintended' consequences of the privatisation of health and social care systems in Italy in light of the pandemic
}

\author{
Andrea Ciarini \\ Sapienza University of Rome, Italy
}

\section{Stefano Neri}

University of Milan, Italy

\section{Summary}

This article analyses the long-term effects of privatisation and marketisation on the Italian regional health and social care systems. The research focuses on three Italian regions - Lombardy, Veneto and Lazio - which are representative of three different models of governance in these sectors. We examine the effects of privatisation and marketisation on the health and social care system by discussing how the regional health-care systems have managed the impact of the COVID-19 pandemic. We also shed light on the dramatic consequences of the pandemic crisis on employment levels and working conditions.

\section{Résumé}

Cet article analyse les effets à long terme de la privatisation et de la marchandisation sur les systèmes régionaux italiens de santé et d'aide sociale. La recherche se concentre spécifiquement sur trois régions italiennes - Lombardie, Vénétie et Lazio - qui sont représentatives de trois modèles différents de gouvernance. Nous examinons les effets de la privatisation et de la marchandisation sur les systèmes de santé et d'aide sociale en analysant comment les systèmes de santé régionaux ont géré l'impact de la pandémie de COVID-19. Nous mettons également en lumière les conséquences dramatiques de la crise de la pandémie sur les niveaux d'emploi et les conditions de travail.

\section{Zusammenfassung}

Dieser Artikel analysiert die langfristigen Auswirkungen von Privatisierung und Vermarktlichung auf die italienischen regionalen Gesundheits- und Sozialfürsorgesysteme. Die Forschung

\section{Corresponding author:}

Andrea Ciarini, Department of Economic and Social Sciences, Sapienza University of Rome, Via Salaria II3, 00I98, Rome, Italy.

Email: andrea.ciarini@uniromal.it 
konzentriert sich speziell auf drei italienische Regionen - die Lombardei, Venetien und Latium - die repräsentativ für drei verschiedene Modelle der Governance in diesen Sektoren sind. Wir untersuchen die Auswirkungen von Privatisierung und Vermarktlichung auf das Gesundheits- und Sozialsystem, indem wir erörtern, wie die regionalen Gesundheits- und Pflegesysteme die Auswirkungen der COVID-19-Pandemie bewältigt haben. Wir beleuchten auch die dramatischen Folgen der Pandemiekrise auf das Beschäftigungsniveau und die Arbeitsbedingungen.

\section{Keywords}

Health care, privatisation, industrial relations, trade unions

\section{Introduction}

The economic crisis and subsequent austerity policies have put welfare services under strong pressure, forcing many countries in Europe to reduce social provision with a consequent worsening of working conditions for care workers. Italy is one of the southern European welfare regimes hardest hit by the wave of marketisation and privatisation as a consequence of structural reforms, forcing local institutions and regions to reduce their social spending. On top of this, austerity measures include significant cuts in public spending, especially at regional level. The Italian National Health Service is regionally based, with the central state determining the budget for each region, and regions and local governments responsible for the organisation and delivery of health and social care services, both domiciliary and residential. During the 'Great Recession', Italian sub-national governments - such as the regions - were forced to accept significant cuts by central government (Bordogna and Neri, 2014; Neri, 2020). This resulted in severe cuts in expenditure in essential services. Furthermore, the new social and economic crisis triggered by the COVID-19 emergency has weakened the ability of local health and social care provisions to cope with social needs, with dramatic consequences for the daily life of the elderly and users affected by severe multi-dimensional needs.

Over the period 2010-2019, the health and social care systems suffered severe financial cuts, on top of decades of austerity, territorial fragmentation and privatisation favouring private providers at the expense of public services, especially primary care and social assistance, which have decreased dramatically. Privatisation has resulted in a worsening of working conditions and a marked labour shortage in public health authorities. The article examines three Italian regions Lombardy, Veneto and Lazio - which are representative of the diverse models of regional healthcare governance in the aftermath of privatisation and decentralisation. The Lombardy region has been strongly committed to promoting marketisation and privatisation in health and social care since the end of the 1990s, creating 'quasi-markets' in which public and private providers compete to attract patients and users (Le Grand and Bartlett, 1993). Whereas Veneto has promoted a model based on a mix of competition and cooperation in health-care governance, Lazio's governance model has been dominated by cost containment-oriented top-down strategies because of the huge deficit accumulated over recent decades. The differences between these models have been markedly evident during the COVID-19 pandemic, with diverse approaches to COVID-19 revealing differences in how each region has managed the pressures to reduce social spending and public services. Hence, the main research question is: how do privatisation and marketisation in the health-care system in Italy account for the social effects of the pandemic, and why? We will answer these questions in the light of six interviews with trade unionists, at both regional and 
local level. These interviews are complemented with secondary data, as well as a comparative analysis of the three regional contexts.

The article is organised as follows. First, we provide an overview of the literature on privatisation and outsourcing in health and social care services in Italy, as well as a look at regional regulatory models, highlighting some differences in terms of marketisation and privatisation. Second, we discuss trends towards privatisation and analyse the main changes occurring in the Italian health and social care system in light of the COVID-19 emergency, highlighting trade union strategies aimed at coping with these changes. Finally, we provide a general interpretation of emerging trends, and conclude.

\section{Literature review}

European welfare regimes have been subjected to severe cuts in welfare provisions, which have reduced the fiscal space for welfare recalibration (Hemerijck, 2013, 2017). In many countries welfare supply has increasingly become market-led through the imposition of outsourcing and the reduction in public direct provision because of the mounting budgetary constraints and pressure to reduce public spending. Privatisation undermines public social protection by expanding market provision under the aegis of neoliberal economic doctrines (Streeck, 2018).

Against this background, many strands of the literature have pointed to transformations in social policies that have paved the way for the subordination of welfare provision to 'market logic'. Some scholarly work has analysed privatisation resulting from changes occurring in the governance of care at local level. These studies have focused on outsourcing and various public-private initiatives aimed at providing more services with fewer resources. As Crouch has pointed out (2015), outsourcing, the creation of special agencies and other public-private partnerships are a means of subordinating the state to the market. These institutions reduce public legitimacy, often making it difficult for citizens to distinguish between the state and private providers. Outsourcing and market competition lead to a fragmentation of the public sector, opening up new opportunities for private providers in public service delivery.

Pressures towards marketisation and privatisation affect the boundaries between public and private providers, with the emergence of new hybrid forms of welfare provision. Some scholars (Azemati et al., 2013; Hazenberg and Hall, 2016) have expressed concerns about this. First, there is a risk of a further drive towards the privatisation of public services. Secondly, they have emphasised the increasing focus on a few large profit and non-profit organisations able to provide most of the services outsourced by public authorities (Azemati et al., 2013). For example, in the United Kingdom, these pressures have fostered so-called 'spin-outs' within the NHS so as to support (public) employee ownership through social enterprises, mutual enterprises and cooperatives (Hazenberg and Hall, 2016). In other countries, including Italy (and especially in the northern regions), 'spin-outs' have emerged as an alternative to outsourcing and public provision, with an increasing number of municipalities transferring social and long-term care services to 'special firms' or 'foundations', with a distinct public or private legal status. In Italy, foundations, as well as external providers ('personal service firms') have resulted also from the transformation of IPABs (Istituzioni pubbliche di assistenza e beneficienza), which was implemented after 2000.

Special firms, personal service firms and foundations are subject to different kinds of monitoring and control systems by municipalities and other local government authorities, but they have managerial autonomy from public bodies and, in the case of foundations, private legal status. Given the pressures to reduce public spending and to apply for new funding, the spread of these public-private organisations impacts on both relations between public and private providers in the 
social care market, and the workforce employed in social and long-term care services, further worsening pay and working conditions (Dorigatti et al., 2020; Neri, 2020).

The literature on local/regional retrenchment and on the effects of privatisation on users and social workers has highlighted the impact of privatisation and decentralisation. A new business model has emerged that relies on the use of casual and deskilled workers and replaces the idea of care as a public concern. In this scenario, the rise of quasi-markets, in both health and social care, and the spread of cash for care schemes in social care have led to growing competition among public and, especially, private providers, including big transnational companies owned by private investors. This is the case, for instance, in the Nordic countries, where such companies are on the rise, selling their services to local municipalities (Vaittinen et al., 2018). While eroding public provision, outsourcing and market-like mechanisms also affect the quality of care and working conditions of private care workers, who are forced to do more with fewer resources (Meagher and Szebehely, 2018).

In the health-care sector, service externalisation and privatisation have mainly concerned ancillary services (Mori, 2020). However, substantial changes have also been introduced within public providers and the health-care system. According to the principles of 'New Public Management' (Hood, 1991; Pollitt and Bouckaert, 2011), managerial tools and practices typical of private sector companies have been adopted by public providers since the 1980s, involving employment relations and human resource management (Bach and Della Rocca, 2001; Bach and Bordogna, 2011). Market-like and competitive mechanisms have been introduced in most European health-care systems since the early 1990s (Rothgang et al., 2010). In national health services, such as the one in Italy, these reforms have increased the role of private for-profit and non-profit organisations in service provision. Similar dynamics also affect social care, in which, in many countries, the role of private providers has always been stronger than in health care.

'New public management' and increased competition resulting from market-like mechanisms have undermined the traditional self-regulation and dominance of the health-care professions and have contributed to important changes in their 'professionalism' (Evetts, 2011; Noordegraaf, 2015). Alongside this, there has been an overall worsening in pay and working conditions, especially among those working in outsourced services (Bach, 2016; Grimshaw et al., 2015; Mori, 2017).

Outsourcing has challenged public service industrial relations by altering the distinction between public and private employment. According to many authors (Flecker and Meil, 2010; Marchington et al., 2005), this implies a progressive shift towards a uniform deregulation of labour relations, substantially driving down labour costs. In Italy, recent analyses suggest a different picture of employment relations in the public sector. Pressures towards outsourcing and budget constraints have resulted in a strong dualisation between the private workforce, which has borne the brunt of cost containment strategies and outsourcing, and public workers, who have remained highly protected and unionised. This dualism reflects the institutionalisation of a two-tier workforce within public organisations (Mori, 2020), with huge consequences in terms of employment protections and inequalities within the labour market. This institutional configuration has further weakened trade unions, caught between the need to mitigate the harmful impacts of outsourcing on public sector workers and obstacles to representing 'outsiders', who are left at the mercy of private employers.

\section{Decentralisation of health and social care in Italy and the emerging regional models}

The Italian National Health Service (NHS) was set up in 1978, replacing the previous social health insurance system. In the first period (1978-1992), the governance of the NHS was shared between the central state, regions and municipalities. The 1992-1993 reforms (Legislative Decrees No. 502/ 
Table I. Model of governance in the Italian health-care system.

\begin{tabular}{llll}
\hline & Competition-led & Cooperation-led & Bureaucracy-led \\
\hline Regions & Lombardy & Emilia-Romagna; Tuscany; Veneto & Southern regions and Lazio \\
\hline
\end{tabular}

1992 and No. 517/1993) regionalised the NHS by concentrating most powers and responsibilities in the organisation and management of health-care services in the 20 regions and the two autonomous provinces of Trento and Bolzano. This includes the management of the public organisations locally responsible for the health of the population and the delivery of health-care services, local health firms or authorities (Aziende Sanitarie Locali) and hospital firms or trusts (Aziende Ospedaliere).

Regionalisation was strengthened in 2001 by amendments to Title V of the Constitution introduced by Constitutional Act No. 3/2001.

This evolution in health care also affected social care, which had always been decentralised, with a pivotal role allocated to local government. Although municipalities maintained their importance, after 2001, the regions considerably increased their role in social care, aimed at increasing the level of integration between social and health care.

Central government maintains an essential role in health and social care, defining the 'essential levels of care' to be ensured all over Italy (but implemented almost exclusively in health care), and controlling most financial resources. Fiscal autonomy is very limited. The Conference of StateRegions aims at ensuring shared governance of national and social policy between the central state and the regions, as well as in other decentralised policy sectors. Its activity has always been focused on controlling spending. To this end, a State-Region entente introduced a recovery plan mechanism in 2005, within the NHS. This is a multi-step mechanism for monitoring regional expenditure and recovery plans in the case of excessive deficits: if a region accumulates serious deficits and misses spending targets, measures such as an increase in regional taxes and tight supervision of regional expenditure policies by the Ministry of Economy and Finance (MEF) are activated. The central government and the MEF may also appoint a commissioner for NHS administration in that region and impose measures to reduce the deficit.

Along with regionalisation, the 1992-1993 reform and subsequent legislation introduced managerialisation and managed competition (Enthoven, 1985), subsequently converted to managed cooperation (Light, 1997), in service provision. At national level, only some general rules were set, requiring the regions to undergo far-reaching regulatory intervention to define the implementation of the managed competition or cooperation, with the possibility of adopting very different arrangements in health and social care.

The literature has identified three main regional models in the governance of health care, strongly affecting social care. These models emerged in the late 1990s and have largely been consolidated, with some adjustments. According to the literature (Mapelli and Boni, 2010; Neri, 2011), they can be summarised as follows (see Table 1).

In Lombardy, the centre-right government, which has been in power since 1995, has experimented with competitive regulation by creating 'quasi-markets' (Le Grand and Bartlett, 1993) in health and social care. A quasi-markets system is based on the split between service purchasers, the regions or the local health authorities, and public or private service providers, which compete with one another. Lombardy is the only Italian region that opted for a nearly complete purchaser (commissioner)-provider split, following the UK experience. Moreover, between 1996 and 
2002, Lombardy expanded the number of private organisations providing health-care services to the NHS and ensured the maximum degree of patient choice in order to promote competition between public and private providers. As prescribed by national regulation, it adopted regional tariffs for in-patient hospital services based on the Diagnosis Related Group (DRG) classification system. ${ }^{1}$ This system promotes efficiency but also has many risks in terms of appropriateness of services provided. Lombardy extended the application of DRGs to an extraordinary range of services (including, for example, psychiatric and women's health services), compared with the other regions.

Starting from 2002, Lombardy reduced the incentives to competition and introduced some arrangements to prevent overspending and ensure effective cost-containment. It did not abandon its policy approach aimed at promoting quasi-markets and a more prominent role for private providers in health and social care, however. The later 2015 reform pursued a complete purchaser-provider split, while, in the following years, the reform of chronic care followed the previous trend towards marketisation and privatisation in service provision. In social and long-term care, this orientation was expressed by the spread of private non-profit foundations created by the conversion of public providers (such as the already mentioned IPABs), to a greater extent than in the other regions.

The overall result of this set of policies was the consolidation of a very strong and highly specialised hospital and residential care system, to the detriment of primary, community and home care. Over the years, the purchaser-provider split and quasi-markets mechanism have been implemented mainly according to the configuration and needs of hospital and residential care, penalising primary and community care, which are less developed than in other Italian regions. This would prove to be very important when the COVID-19 emergency suddenly hit Lombardy in the first months of 2020.

The second governance model is based on the principles of cooperation between public and private health-care organisations. In this model, which can be found in the central-northern and north-east regions, regional policy is aimed at building integrated networks of care, wherein each organisation, public or private, is an irreplaceable node and is complementary, not in competition, with the other nodes. Integration has the goal of reducing excessive capacity and redundancy in services. In regions such as Emilia-Romagna, Tuscany and Veneto, the purchaser-provider split is limited, the use of DRGs is not as extended as in Lombardy and the accreditation of new providers has always been subordinated to needs identified by regional planning (Neri, 2011). These arrangements allow primary and community services to play a greater role in the health and social care system, compared with Lombardy or other Italian regions. Although these regions differ in how they pursue integration and in the role of private providers, they all exhibit greater investment in community, out-patient and home care. During the first wave of the pandemic (February-May 2020), this emerged clearly, especially in the case of Veneto.

Concerning competition and cooperation, there are other regions that make no clear choice for one or the other option, often showing a tendency to swing back and forth between the two. Mapelli and Boni (2010) include these regions in a bureaucratic model in which traditional command-and-

1 In this system, patients are grouped together under DRGs according to criteria, such as principal diagnosis, presence of a surgical procedure, age, presence of co-morbidities and other criteria. 'As all patients within the same DRG are expected to have similar hospital resource use, this classification system can be used to reimburse the cost of in-patient hospital care services' (Böcking and Trojanus, 2008). DRGs were first adopted in the US Medicare programme and then progressively adopted, in many forms, in European countries. 
control mechanisms are matched with a rare ability to ensure the governance of the health-care system, especially in managing relations with private providers, vital in some of these regions (Lazio, Campania, Sicily and most of the southern regions). Since the period 2007-2010, health policy in many of these regions has been dominated by financial problems, which forced them to adopt the recovery plans, under MEF supervision.

In Lazio, the health-care system has for a long time found it difficult to reach a financial balance. Together with the southern regions, Lazio has suffered from the most severe conditions because of its health spending deficit, leading to very tight budgetary plans with the Ministry of Health and the MEF (Toth, 2014). Because of its deficit, Lazio was the first Italian region to be placed under compulsory administration by central government. This had a dramatic impact on territorial health-care provision. As a consequence, regional governance has been dominated by financial constraints, with less room for manoeuvre in terms of negotiations and mutual agreements with all the actors involved in designing and delivering health-care and social services.

\section{Austerity policies and employment relations in health and social care in the wake of the economic crisis}

Cost containment is a traditional driver of Italian health policy. Its importance increased after Italy's entry into the euro area in 1999, with the related commitments to meet the economic and financial convergence criteria of the Stability and Growth Pact, signed in 1997 and amended in 2005. In the case of Italy, this especially entailed reducing the huge government consolidated debt, which has always been one of the highest in the EU and nearly always (well) over 100 per cent of GDP (134.7 per cent of GDP in 2019, before the pandemic). International pressures to adopt a restrictive budgetary policy became particularly strong after the beginning of the economic crisis in 2008-2009, especially after the 2010-2011 sovereign debt crisis.

Several austerity packages were adopted (Bordogna and Neri, 2014), with a varying mix of tax increases and cuts in public sector expenditure and employment. The Italian National Health Service was hit by severe cuts in resources and an increase in patients' co-payments. The average annual growth rate of NHS financing decreased from 7.4 per cent in 2001-2005 to 3.1 per cent in 2006-2010, and 0.1 per cent in 2011-2019 (GIMBE, 2019). From 2008 to 2019, public expenditure on health care decreased slightly from 6.6 to 6.4 per cent of GDP, the same level as in Spain, but 3-3.5 percentage points less than in France and Germany, and 1.6 percentage points less than in the United Kingdom (OECD, 2020a). Current per capita public expenditure on health care increased by 15.8 per cent, rising from US\$2278 in 2008 to US\$2706 in 2019 (current prices, purchasing power parities; OECD, 2020a). In the period, current per capita public expenditure on health care rose from US\$2857 to US\$4501 (+36.5 per cent) in France, from US\$2968 to US\$5648 $(+47.4$ per cent) in Germany, and from US\$2634 to US\$3619 in the United Kingdom $(+27.2$ per cent). Only Spain, among comparable European countries, reported similar values to Italy (US\$2560 in 2019). Similar gaps between Italy and the above-mentioned countries have emerged also in relation to total expenditure on health.

As in other public services (Bordogna and Neri, 2014), restrictions on personnel expenditure and staff turnover were widely implemented, with NHS staff being cut from 693,600 to 648,507 (6.5 per cent) between 2009 and 2018 (Ragioneria Generale dello Stato data-warehouse). Data on doctors analysed by Vicarelli (2020) confirm this reduction for the NHS ( -9.5 per cent between 2010 and 2017), while in the same period the number of doctors increased by 15.7 per cent in the private sector. Staff cuts also resulted in an increase in staff workload in the NHS (Vicarelli, 2020). 
In 2010, national collective bargaining in the public sector was suspended until 2015, while local bargaining was severely limited. Staff pay in the NHS, as well as in local government, remained at 2010 levels for nearly the whole decade, while externalisation of ancillary services and new spin-outs in long-term care and social care caused increasing fragmentation in employment relations and working conditions. New national collective agreements for both the NHS and local government staff were signed only in 2018.

In the private sector, apart from a restricted group of professional workers who have enjoyed salary rises in recent years, most employees have seen their contractual conditions worsen, with lower wages and lower levels of training and qualifications. This situation was the result not only of the impact of austerity on public finances and the rise of privatisation and spin-outs, but also of the dynamics of employment relations in the past decade.

In the private for-profit health-care sector, the main concern of employment relations has been the renewal of the national labour agreement, which had been signed in 2004. Since then, negotiations have stalled owing to the opposition of employers. The employers' associations remained hostile to any improvement in pay and working conditions. Low tariffs for contracted services from the NHS, as well as from local government institutions, reduced the room for wage increases, with hospitals, health authorities and municipalities being forced to reduce their budgets.

The non-profit sector has followed the same path, with very fragmented collective bargaining and even worse working conditions than the private sector, due to low wages and contracting out. The presence of different employment agreements created unequal conditions for workers. In terms of pay and other components of the employment relationship (such as working hours, holiday, time off and leave), the most unfavourable agreements are those in the private for-profit and non-profit sector (Dorigatti et al., 2020; Mori, 2020).

Austerity policies entailed a reduction not only in human but also in structural resources. From 2008 to 2018, hospital beds were reduced from 3.8 to 3.1 per 1000 inhabitants (OECD, 2020b), nearly half the number in France (6.0 in 2018) and less than half the number in Germany (8.0). De-hospitalisation, a long-term trend that started in the late 1980s, should have been balanced out by the development of community and home care services, but this was severely limited by the restrictions on public finances (Neri, 2021). Substantial cuts have also affected procurement and investments. The Italian NHS was thus severely underfinanced and under-resourced when the pandemic started in 2020.

Austerity policies intensified earlier trends to transform the NHS into a more 'hybrid' system, characterised by public retrenchment and the growing role of privatisation and corporatisation in health-care financing. Occupational and corporate health funds rose from a minor share to more than one-third of total employees in the past decade (Ascoli et al., 2018; Neri, 2019a). The spread of health occupational funds, fostered by fiscal incentives, was accepted by the unions, which saw it as compensation for the lack of or restrictions on wage increases in an era of economic crisis (Pavolini et al., 2018).

The austerity measures have been imposed by central government and especially by the Ministry of Economy and Finance (MEF), without any real room for negotiations with the regions and organised interests. The importance of the MEF's role in health policy was also increased by the implementation of the recovery plan mechanism. Since 2007, all nine southern and centralsouthern regions (excluding the small region of Basilicata) have been involved in a recovery plan, compared to only two out of the 11 northern and central-northern regions. As regions subject to and those not subject to the recovery plans have very different levels of autonomy in health policy, the implementation of this mechanism has de facto introduced a sort of 'differentiated health-care federalism' between Italy's north and south (Frisina Doetter and Neri, 2018; Neri, 2019a, 2019b). 
Table 2. Doctors and nurses per 1000 inhabitants.

\begin{tabular}{lcc}
\hline & Doctors per 1000 inhabitants (2018) & Nurses per 1000 inhabitants (2018) \\
\hline Italy & 4.0 & 5.8 \\
France & 3.2 & 10.5 \\
Germany & 4.3 & 13.1 \\
United Kingdom & 2.8 & 7.8 \\
Spain & 4.0 & 5.7 \\
\hline
\end{tabular}

Source: OECD (2020b).

In some ways, this anticipated the formal request for more autonomy in many policy sectors, including health and social care, promoted by three northern regions (Lombardy, Veneto and Emilia-Romagna) since 2017 and negotiated until the outbreak of the pandemic, which suspended the process in 2020 .

\section{Health-care labour market and union strategies during COVID- 9}

As in many other European countries, human health and social work activities have been steadily rising in recent years in Italy. Between 2008 and 2019, employment growth was about +17.7 per cent (OECD, 2020b). However, employment in this sector is still limited compared with many European countries. While in 2018 the share of employees in health and social care in the United Kingdom was over 6.5 per cent of the resident population and in France and Germany it amounted to 6.0 to 6.1 per cent, in Italy the ratio was just over 3 per cent of the population ( 3.15 per cent), a value similar to Spain (Argentin et al., 2020). The gap with other countries is only partially compensated when one also includes workers directly employed by families (estimated at nearly $750,000)$.

Table 2 shows the number of registered doctors and nurses per 1000 inhabitants in 2018 in the countries already considered. The shortage of nurses is evident compared with other European countries: although their number has increased (5.8 per 1000 inhabitants in 2018), the gap with France and Germany, which was already large, has further increased over the past ten years. As to doctors, the situation is in line with or better than in other European countries. However, it is widely recognised that the division of labour in the Italian health-care system is still more centred on doctors than in the United Kingdom or in many continental European countries, such as France and Germany. This means that the Italian health-care system needs more doctors than health-care systems elsewhere.

For this reason, the large-scale retirements planned in the coming years might be particularly serious. As Vicarelli and Pavolini (2015) have pointed out, Italy is one of the OECD countries with the highest percentage of older physicians and the lowest percentage of younger ones. In 20172018, more than 50 per cent of physicians were 55 years of age or more; in France and Germany, which share a similar problem, this percentage amounted to 44-45 per cent, while in Spain the share was only 33 per cent and in the United Kingdom a mere 12 per cent (OECD, 2020b). According to a frequently quoted study by the main hospital doctors' union, Anaao-Assomed, there is already a shortage of clinicians, particularly in specialties such as emergency health care, anaesthesiology, internal medicine, paediatrics and also in general practice (Anaao-Assomed, 2020). 
Staff shortages, especially in the case of GPs, have contributed to the limited development of primary and community care, which has emerged as a critical issue in many regions (such as Lombardy) during the COVID-19 pandemic. In addition, shortages in hospital specialties such as anaesthesiology or internal medicine became very evident in 2020-2021. Furthermore, the shortage of nurses has been highlighted by the media and public opinion, not only in all health-care services but also, and especially, in residential home care services.

After a decade and more of deteriorating pay and working conditions, as well as of restrictions on collective bargaining and substantial exclusion from national policy-making, the unions tried to revitalise their strategy under the new conditions created by the COVID-19 emergency. In continuity with a strategy pursued in recent years, they have focused on inclusive bargaining, in an attempt to reduce differences in working conditions in accordance with workers' positions within the labour market, whether temporary or permanent. This entailed reducing the gaps between pay and working conditions in the public and in the private sector.

As a workers' delegate in the Lombardy region pointed out:

The current system of collective bargaining in the private health sector is inadequate because it reflects a strong fragmentation in labour relations and contracts, with different standards and wages for the same jobs. Thus, our main target has been to bridge the gap between the NHS and the working conditions of private employees. This is, however, the main problem for us, because continuing cuts and contracting out have led to a persistent fragmentation in the labour market. In order to do more with less, health authorities have externalised services and workers, with negative consequences on wages in the private sector. (Interview with a worker representative in Lombardy)

At regional level, service externalisation and privatisation have gone hand in hand with a progressive increase in the role of private providers in health-care systems, providing both contracted services for publicly funded health-care systems and health services for corporate and private health insurance. All three Italian regions analysed here have followed this path, although with different governance models. In each of these regions, union representatives and workers' delegates have emphasised how pressures to increase competition and management practices underpinned by the 'new public management' doctrine have generally caused a worsening of wages and working conditions, especially for those working in outsourced services. As a worker representative in the Veneto region argued:

\footnotetext{
Although in the Veneto region the governance of the regional health-care system was less affected by privatisation and new public management-inspired techniques than the Lombardy region, union efforts to mitigate the spread of contracting out were hindered by the hostility of private providers to increased labour costs. Even in the period before the pandemic, the problem was the lack of resources and specific professionals (doctors, nurses, specialists). All this has led, also here in Veneto, to a shift towards the private sector, and this has created differentiation in wages and working conditions, especially in non-hospital care. (Interview with a worker representative in Veneto region)
}

The pandemic provided an opportunity to demand better working conditions and a rebalancing of relations between the public and private health and social care sectors. This strategy was linked to demands for major financial investment and staff hiring in the NHS in order to strengthen the public system. This was also justified by evidence that the emergency, especially in the first months of the pandemic, was faced mainly by public organisations, to the detriment of regions in which private provision is stronger, such as Lombardy. 
Through an unprecedented effort, after the beginning of the pandemic in 2020 the Italian government responded by allocating additional resources both to the hospital system and to prevention, primary and out-patient care. Public spending on the Italian NHS has increased substantially, reaching $€ 119$ bn in 2020 ( +4.5 per cent compared with $2019 ;+6.1$ per cent compared with 2018 ) and $€ 121.4 \mathrm{bn}$ in 2021 (Italian Parliament, 2021). Since the outbreak of the pandemic government interventions have focused on strengthening home care and community care, committing regions to establishing special units for continuity of care (USCA) aimed at managing COVID-19 patients at home.

Moreover, several measures have been adopted for staff recruitment, including extraordinary recruitment plans (with extra national funds) for doctors, nurses and other health professionals; the abolition of the national professional exam for doctors, previously compulsory for those entering the medical profession; and the possibility for regions and health-care organisations to take extraordinary decisions aimed at extending working time and the level of flexibility in managing the health-care workforce. From March to November 2020 more than 36,000 employees were hired by the NHS, most in temporary positions. Recruitment followed in 2021, also in relation to the vaccination programme.

The government also introduced a 'Corona bonus' for doctors, nurses and other health professionals. Ancillary workers in health services were excluded from the bonus, although they often share the same increase in workload as health professionals. This caused protests from ancillary worker unions, which obtained little compensation for the occupational groups they represent.

There have been very different reactions from the regions, however. Over the years, Lombardy's health-care system has become more weighted towards private health-care providers, including out-patient services. The strengthening of private hospital services has contributed to the weakening of local public health and primary care services. With the outbreak of the pandemic, hospitals were the only point of access, however, swiftly becoming overwhelmed. In this scenario, while Lombardy failed to manage the coronavirus crisis, other Italian regions, such as Veneto and to some extent also Lazio, managed to contain the health emergency more effectively. In the Veneto region, the choice to promote integration between local care networks in order to reduce excess capacity and redundancy in hospital services and boost the availability of well-equipped primary and community care, helped to contain the infection through massive contact tracing and case investigations. The Lazio region has adopted a different strategy. At the beginning, contact tracing relied mainly on public health-care organisations, although with the unintended effect of massive delays in diagnosis. It later introduced specific rules to involve private structures in contact tracing, which were then changed, with huge consequences for the pandemic. After the initial difficulties in coping with the pandemic, public action was strengthened, with a high degree of coordination between the region, general practitioners and local health authorities. In the midst of the health emergency, the Lazio region, on the one hand, centralised some functions of management and control and, on the other, strengthened local health authorities.

Against this background, the union strategy has followed two main paths. On the one hand, the trade unions' main concern has been to obtain as soon as possible the right equipment to protect workers, especially in nursing homes and hospitals. On the other hand, they relaunched collective bargaining, signing new agreements with institutions and private providers. On 25 March 2020, CGIL, CISL and UIL signed an agreement on workers' health and safety with the Ministry of Health, involving new preventive measures to protect workers in terms of protective equipment and tests for personnel exposed to the virus. Moreover, the agreement entailed new emergency measures to increase staffing in the health-care system. One worker representative stated: 
The situation today is as follows: the new measures have involved resources and planning that had never been seen previously. A crucial point for us is the concrete monitoring of the regional initiatives implementing the national guidelines. The problem is that there is still a very wide disparity between public and private providers. There are private providers that apply different employment contracts putting downward pressure on salaries. And the new recruitment in public providers could imply unintended consequences. For instance, currently nurses are leaving employment in private nursing homes. Now, the private health-care contract has just been renewed after 14 years. And this is positive for us. But I have doubts about its scope because it does not include all the non-hospital facilities that have not adopted this contract to date, such as private nursing homes. (Interview with a worker representative)

Another respondent (worker representative in the Lazio region) added:

This emergency affects many other services that have been outsourced but are in close contact with the public health-care system. There are no acceptable working conditions in cleaning, surveillance, catering. These workers work inside hospitals and are excluded from tracing and health surveillance. This fragmented labour market is a problem that needs to be addressed by standardising rights and working conditions, so that they are better for all, not just some. The region is handling the health emergency well. Public services have been strengthened. The strategy has been well coordinated centrally. The problem now is to transform this organisational effort into a revitalisation of public health care. (Interview with a worker representative in Lazio region)

\section{Conclusions}

In this article, we have analysed the long-term effects of privatisation in light of the COVID-19 emergency at the regional level in Italy. The three regions we have focused on (Lombardy, Veneto and Lazio) reflect different governance models for health-care supply, with different approaches to managing pressures to reduce social spending and to cope with the pandemic. As we previously mentioned, Lombardy was particularly hit by the spread of the virus in the first wave of the pandemic (February-May 2020), which quickly led the health and residential social care systems to collapse. At the same time, Lombardy has been at the forefront in Italy promoting privatisation and quasi-markets in the health and social care system, with very significant consequences for local services and a growing concentration of resources and patients towards private providers. This has had dramatic consequences on the management of the emergency. The pandemic has significantly affected the different regions, and path dependency has played a decisive role in defining institutional responses to the health emergency. However, beyond these differences, there is one common trait.

Although the regions have adopted different governance models, they have all been under strong pressure to cut public spending, undermining especially primary and community care, as well as to outsource public services. In each of these regions, union representatives and workers' delegates have emphasised how pressures to increase competition and new public management practices have generally worsened pay and working conditions, especially for those working in outsourced services. Union efforts have also been hampered by opposition from employers, who want to keep labour costs down, and the widespread use of low-cost home care services provided by individual carers.

Nevertheless, the pandemic has also opened up unprecedented room to manoeuvre for the social partners. Faced with the negative consequences of privatisation, the trade unions are now pursuing 
a strategy of standardising employee rights and working conditions, involving both private and public providers. The renewal of the private health-care national collective employment agreement after 14 years is an example of this. While the trade unions have often been seen as conservative actors, concerned only with protecting insiders and permanent workers, in this case, their strategy is aimed at reducing labour market dualism by including all types of employment contracts within common standards and contractual rights. Together with the massive public investment, which should benefit the NHS in the next few years thanks to national and EU resources, this strategy could reduce the dualism between workers who perform the same tasks, but have different employment rights, which at present is the reality in many regional health-care systems.

\section{Funding}

This research received no specific grant from any funding agency in the public, commercial, or not-for-profit sectors.

\section{References}

Anaao-Assomed (2020) La programmazione del fabbisogno di personale medico, proiezioni per il periodo 2018-2025: curve di pensionamento e fabbisogni specialistici. Available at: http://www.anaao.it/public/ aaa_8949220_fabbisogni_2018-2025_versione_05_01_2019.pdf (accessed 19 May 2021).

Argentin G, Fellini I and Neri S (2020) Chi fa il welfare? Gli occupati nei settori dell'istruzione, della sanità e dei servizi sociali. La Rivista delle Politiche Sociali 3/2020: 47-74.

Ascoli U, Natali D and Pavolini E (2018) Still a weak occupational welfare in Southern Europe? Evidence from the Italian case. Social Policy \& Administration 52(2): 534-548.

Azemati H, Belinsky M, Gillette R, Liebman J, Sellman A and Wyse A (2013) Social impact bonds: Lessons learned so far. Community Development Investment Review 9(1): 22-32.

Bach S (2016) Deprivileging the public sector workforce: Austerity, fragmentation and service withdrawal in Britain. The Economic and Labour Relations Review 27(1): 11-28.

Bach S and Bordogna L (2011) Varieties of new public management or alternative models? The reform of public service employment relations in industrialized democracies. The International Journal of Human Resource Management 22(11): 2281-2294.

Bach S and Della Rocca GD (2001) The new public management in Europe. In: Dell'Aringa C, Della Rocca G and Keller B (eds) Strategic Choices in Reforming Public Service Employment. London: Palgrave Macmillan, pp. 24-47.

Böcking W and Trojanus D (2008) Diagnosis related groups (DRGs). In: Kirch W (ed.) Encyclopedia of Public Health. Dordrecht: Springer, p. 40. Available at: https://doi.org/10.1007/978-1-4020-5614-7_790 (accessed 20 May 2021).

Bordogna L and Neri S (2014) Austerity policies, social dialogue and public services in Italian local government. Transfer: European Review of Labour and Research 20(3): 357-371.

Crouch C (2015) The paradoxes of privatisation and public service outsourcing. Political Quarterly 86(S1): $156-171$.

Dorigatti L, Mori A and Neri S (2020) Public, private or hybrid? Providing care services under austerity: The case of Italy. The International Journal of Sociology and Social Policy 40(11/12): 1279-1300.

Enthoven AC (1985) Reflections on the Management of the National Health Service. London: Nuffield Provincial Hospitals Trust.

Evetts J (2011) A new professionalism? Challenges and opportunities. Current Sociology 59(4): 406-422.

Flecker J and Meil P (2010) Organisational restructuring and emerging service value chains - implications for work and employment. Work, Employment and Society 24(4): 680-698. 
Frisina Doetter L and Neri S (2018) Redefining the state in health care policy in Italy and the United States. European Policy Analysis 4(2): 234-254.

GIMBE (2019) $4^{\circ}$ Rapporto GIMBE sulla sostenibilità del Servizio Sanitario Nazionale. Bologna: Fondazione GIMBE. Available at: www.rapportogimbe.it (accessed 20 May 2021).

Grimshaw D, Rubery J, Anxo D, Bacache-Beauvellet M, Neumann L and Weinkopf C (2015) Outsourcing of public services in Europe and segmentation effects: The influence of labour market factors. European Journal of Industrial Relations 21(4): 295-313.

Hazenberg R and Hall K (2016) Public service mutuals: Towards a theoretical understanding of the spin-out process. Policy \& Politics 44(3): 441-463.

Hemerijck A (2013) Changing Welfare States. Oxford: Oxford University Press.

Hemerijck A (ed.) (2017) The Uses of Social Investment. Oxford: Oxford University Press.

Hood C (1991) A public management for all seasons? Public Administration 1(9): 3-19.

Italian Parliament (2021) Il livello di finanziamento del Servizio Sanitario Nazionale, Servizio Studi Camera dei Deputati, January 2021. Rome: Italian Parliament.

Le Grand J and Bartlett W (eds) (1993) Quasi-Markets and Social Policy. Houndmills, Basingstoke: Macmillan.

Light D (1997) From managed competition to managed cooperation: Theory and lessons from the British experience. The Milbank Quarterly 75(3): 297-341.

Mapelli V and Boni S (2010) I sistemi di governance dei servizi sanitari regionali. Quaderni Formez 57. Roma: Formez.

Marchington M, Grimshaw D, Rubery J and Willmott H (eds) (2005) Fragmenting Work: Blurring Organisational Boundaries and Disordering Hierarchies. Oxford: Oxford University Press.

Meagher G and Szebehely M (2018) Nordic eldercare - Weak universalism becoming weaker? Journal of European Social Policy 28(3): 294-308.

Mori A (2017) The impact of public services outsourcing on work and employment conditions in different national regimes. European Journal of Industrial Relations 23(4): 347-364.

Mori A (2020) Employment Relations in Outsourced Public Services: Working Between Market and State. Cham: Palgrave Macmillan.

Neri S (2011) The evolution of regional health services and the new governance of the NHS in Italy. In: Angus D and Boutsioli Z (eds) Health Studies: Economic, Management and Policy. Athens: Atiner, pp. 269-282.

Neri S (2019a) The Italian national health service after the economic crisis: From decentralization to differentiated federalism. E-Cadernos Ces 31: 147-169.

Neri S (2019b) Economic crisis, decentralisation and health inequalities: The case of Italy. In: Tavares AI (ed.) Universal Health Coverage. London: IntechOpen, pp. 103-114.

Neri S (2020) Servizi di welfare e Comuni. Nuove politiche e trasformazioni organizzative. Rome: Carocci.

Neri S (2021) Siamo andati troppo oltre? I processi di ristrutturazione dell'assistenza ospedaliera. In: Giarelli G and Vicarelli G (eds) Libro Bianco. Il Servizio Sanitario Nazionale e la pandemia da Covid-19. Milan: Franco Angeli, pp. 49-57.

Noordegraaf M (2015) Hybrid professionalism and beyond: (New) Forms of public professionalism in changing organizational and societal contexts. Journal of Professions and Organization 2(2): 187-206.

OECD (2020a) OECD Health Statistics 2020, Online Database. Available at: https://stats.oecd.org/Index. aspx?ThemeTreeId=9 (accessed 20 May 2021).

OECD (2020b) Health Care Resources, Online Database. Available at: https://stats.oecd.org/viewhtml.aspx? datasetcode=HEALTH_REAC\& (accessed 19 May 2021).

Pavolini E, Arlotti M, Ascoli U, Leonardi S and Raitano M (2018) The challenge of Occupational Welfare in Italy: Between risks and opportunities. In: Natali D, Pavolini E and Vanhercke B (eds) Occupational Welfare in Europe: Risks, Opportunities and Social Partner Involvement. Brussels: ETUI, pp. 173-192. 
Pollitt C and Bouckaert G (2011) Public Management Reform: A Comparative Analysis - New Public Management, Governance and The Neo-Weberian State. 3rd ed. Oxford; New York, NY: Oxford University Press.

Rothgang H, Cacace M, Frisina L, Schmid A, Wendt C and Grimmeisen S (2010) The State and Healthcare: Comparing OECD Countries. New York, NY: Palgrave Macmillan.

Streeck W (2018) A new regime. The consolidation state. In: King D and Le Galès P (eds) Reconfiguring European States in Crisis. Oxford: Oxford University Press, pp. 139-157.

Toth F (2014) How health care regionalisation in Italy is widening the North-South gap. Health Economics, Policy and Law 9(3): 231-249.

Vaittinen T, Hoppania HK and Karsio O (2018) Marketization, commodification and privatization of care services. In: Elias J and Roberts A (ed) The Handbook of International Political Economy and Gender. Cheltenham, UK; Northampton, MA: Edward Elgar Press, pp. 379-391.

Vicarelli G (2020) La valorizzazione delle risorse umane nel Sistema sanitario nazionale: un principio disatteso. La Rivista delle Politiche Sociali 3/2020: 75-96.

Vicarelli G and Pavolini E (2015) Health workforce governance in Italy. Health Policy, special issue, 119(12): 1606-1612. 